
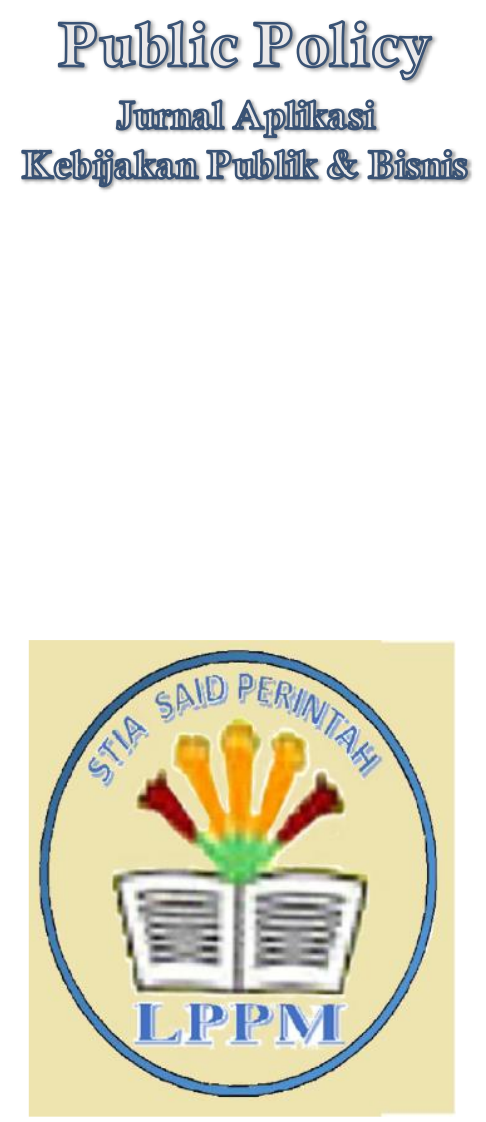

LPPM STIA Said Perintah

Volume 2, No. 1, Maret 2021

https://stia-saidperintah.e-journal.id/ppj

\section{Reformasi Birokrasi Dalam Pelayanan Publik di Kecamatan Tanimbar Selatan Kabupaten Kepulauan Tanimbar}

\author{
Telly Muriany ${ }^{1}$ \\ Victor S. Ruhunlela ${ }^{2}$
${ }^{1}$ IImu Pemerintahan STISIP Kebangsaan Masohi
${ }^{2}$ Ilmu Pemerintahan Fisip Unpatti
tellymuriany@yahoo.co.id

\begin{abstract}
Bureaucratic reform in public services in the south Tanimbar Island urgent. The facts show the South Tanimbar Islands is still faced various obstacles in public services, expecifically in the of education, health and licensing the District level as the spearhead of the South Tanimbar Islands (KKT) government in providing public services. This study used a qualitative because it fits with characteristics of the phenomenon researched verify reform issues that has been and can be done expected in accordance the character of the islands.

The results showed in Tanimbar Selatan Subdistrict, (KKT) was not effective because of the problems faced related to the sub-district government's efforts to implement bureaucratic reform The authority given has not been fully implemented as expected. The aspect of organizational structure, it has implemented the principles arangged in the Government Regulation of the Republic of Indonesia Number 18 of 2016 about Regional Apparatus, it is expeted to prioritze aspects of interests and needs as well as the availability of Regional Government Budgets, the function of authority is often not adjusted to the capacity and comhetence of the apparatus. it is based on likes and dislikes. technology-based information is still lacking, of course it has a negative impact on the low level of public services provided to the community, people are not satisfied believe in the public services provided by these government officials.
\end{abstract}

Keywords : Bureaucracy, Dimension, Institutional, Public Services, Reform 


\section{Pendahuluan}

Pemerintah di negara-nnahuegara berkembang, termasuk Indonesia, memberikan perhatian serius pada usaha reformasi birokrasi dalam dekade terakhir. Agenda kebïakan nasional dalam dekade terakhir di negara-negara tersebut telah mencakup program-program reformasi birokrasi yang ambisius, seperti reformasi program pelayanan publik (Fatile, Jacob O. and Adejuwon, 2010), reformasi pengadaan barang pemerintah (Syquia, 2007; Nahuway \& Tamaela, 2020), reformasiorganisasi dan institusi (Economic Commission for Africa, 2003), serta reformasi penggajian (Kiragu, K. and Mukandala, 2003). Reformasi birokrasi penting bagi negara-negara berkembang karena di negara-negara tersebut birokrasi merupakan mesin utama sektor pemerintah (Kaufman, H., 2011) tetapi birokrasi kekurangan kapasitas untuk memfasilitasi tugastugas pemerintahan secara efektif (Farazmand, 2007). Akibat dari kekurangan kapasitas birokrasi, antara lain, negara-negahra berkembang belum dapat menata sistem kesejahteraan nasional secara efektif.

Reformasi birokrasi seharusnya menjadi solusi bagi pemerintah Indonesia. Akan tetapi, belum mampu menyelesaikan setiap permasalahan-permasalahan yang telah terjadi di Indonesia. Hal ini diesebabkan karena, merajalelanya kasus korupsi, struktur birokrasi yang kaku, kompleks, dan refragmentasi, budaya kekuasaan yang berlebihan, politisasi birokrasi yang semakin meluas, kualitas aparatur yang buruk, serta kualitas pelayanan yang buruk. Kebijakan reformasi yang hanya mengandalkan pada perbaikanremunerasi, pembobotan jabatan, dan penataan organisasi, sebagaimana yang diterapkan di kementerian keuangan dan kementerianpercontohan lainnya, tentu tidak memadai untuk menjawab masalah birokrasi pemerintah di Indonesia yang cenderung sudah sangat kronis dan menular hampir disetiap aspek kehidupan birokrasi (Dwiyanto, dalam Dahyar Daraba H, 2019).

Proses reformasi birokrasi merupakan kegiatan yang tidak akan pernah berhenti. Hal ini karena akan selalu ada perubahan dan dinamisasi dalam pengelolaan negara, serta kompleksitas masalah yang terus berkembang. Dengan demikian, reformasi birokrasi merupakan program berkelanjutan yang harus dicanangkan dalam jangka waktu yang panjang. Oleh karena itu, proses reformasi birokrasi harus terus mendapat dukungan semua pihak. Semua stakeholder atau pemangku kepentingan perlu terus terlibat didalamnya. Baik pihak pemerintah, akademisi, LSM, media, politisi, tokoh adat, tokoh agama, serta unsur-unsur masyarakat lainnya harus tetap menjaga semangat 
perjuangan untuk mewujudkan birokrat Indonesia yang professional, transparan, efektif, dan bertanggung jawab (Priyono, 2014).

Reformasi birokrasi dalam pelayanan publik di Kabupaten Kepulauan Tanimbar (KKT) nampaknya sangat urgen dilakukan saat ini. Fakta menunjukkan bahwa KKT mash dihadapkan dengan berbagai kendala dalam pelayanan publik terutama yang berkaitan erat dengan pelayanan kebutuhan publik dalam bidang pendidikan, kesehatan, dan perizinan terutama pada level kecamatan sebagai ujung tombak pemerintah KKT dalam menyelenggarakan pelayanan publik.

Fenomena kesenjangan pelayanan publik yang belum mampu diselesaikan Pemerintah KKT adalah pelayanan publik pada tingkat kecamatan yang disebabkan oleh rendahnya tata kelola pemerintahan (governance), kedudukan, kewenangan, dan kapasitas struktur Organisasi Perangkat Daerah (OPD) Pemerintah Kecamatan. Hal ini sesuai Peraturan Pemerintah Republik Indonesia Nomor 18 Tahun 2016 Tentang Perangkat Daerah yang ditegaskan pada Pasal 5 ayat (2) bahwa Perangkat Daerah kabupaten/kota terdiri atas; (a) Sekretariat Daerah; (b) Sekretariat DPRD; (c) Inspektorat; (d) Dinas; (e) Badan; dan (f) Kecamatan.

Berdasarkan Peraturan Pemerintah Nomor 18 Tahun 2016 menempatkan kecamatan sebagai posisi terdepan dalam membantu tugas-tugas pemerintahan dan pembangunan dalam rangka meningkatkan koordinasi penyelenggaraan pemerintahan, pelayanan publik, dan pemberdayaan masyarakat desa. Kemudian pelayanan publik menjadi salah satu bagian krusial yang diharapkan dapat menjadi titik fokus perhatian pemerintah KKT. Mengingat kondisi wilayah kecamatan sebagian besar adalah di kecamatan kepulauan dengan kondisi yang marjinal beserta segala akses negatif yang dihadapi, maka perluasan kewenangan pemerintah kecamatan kepulauan dalam rangka optimalisasi pelayanan publik menjadi sangat diperlukan. Untuk meningkatkan kapasitas kecamatan, maka diperlukan reformasi administrasi dalam birokrasi pemerintah KKT, peningkatan kemampuan pemerintah kecamatan dalam pelayanan publik, pengembangan kapasitas organisasi, manajemen, pendanaan, sumber daya, dan sarana prasarana yang memadai.

Permasalahan utama pelayanan publik saat ini pada tingkat kecamatan yang memiliki karakteristik geografis (kepulauan) dan masih terisolasi, sudah tentu memerlukan dukungan sarana prasarana, seperti sarana komunikasi, transportasi yang relatif sangat kurang berdampak pada rendahnya mobilitas orang, barang, dan jasa yang 
secara langsung mempengaruhi perwujudan pelayanan publik yang berkualitas pada tingkat kecamatan. Untuk menyelesaikan permasalahan pelayanan publik, Pemerintah KKT saat ini fokus pada dua program pelayanan publik yang masih sangat kurang yaitu urusan bidang pendidikan dan kesehatan yang sudah diprogramkan pemerintah daerah selama tiga tahun terakhir, meskipun dirasakan masyarakat masih sangat kurang.

Reformasi birokrasi diupayakan menjangkau penataan struktur organisasi dan prosedur serta kebijakan manajemen sumberdaya manusia, upaha reformasi birokrasi makin terprogram dengan terbitnya Peraturan Menteri Negara Pendayagunaan Aparatur Negara (Permenpan) Nomor 25 Tahun 2008 tentang Pedoman Umum Reformasi Birokrasi.

Selanjutnya, pada 2010, terbit Peraturan Presiden (Perpres) Nomor 81 Tahun 2010 tentang Grand Design Reformasi Birokrasi 2010-2025. Visi reformasi birokrasi menurut Perpres ini adalah terwujudnya pemerintahan profesional dan berintegritas tinggi yang mampu memberikan pelayanan prima kepada masyarakat dan manajemen pemerintahan yang demokratis. Area-area reformasibirokrasi menurut Perpres tersebut adalah: (1) organisasi; (2) tatalaksana; (3) peraturan perundangundangan; (4) sumber daya manusia; (5) pengawasan; (6) akuntabilitas; (7) pelayanan publik; dan (8) pola pikir dan budaya kerja aparatur.

Pelayanan publik menjadi salah satu bagian krusial yang diharapkan dapat menjadi titik fokus perhatian pemerintah KKT. Mengingat kondisi wilayah Kecamatan sebagian besar adalah di kecamatan kepulauan dengan kondisi yang marjinal beserta segala akses negatif yang dihadapi, maka perluasan kewenangan pemerintah kecamatan kepulauan dalam rangka optimalisasi pelayanan publik diperlukan saat ini. Untuk meningkatkan kapasitas Kecamatan, maka diperlukan reformasi administrasi dalam birokrasi pemerintah KKT, peningkatan kemampuan pemerintah kecamatan dalam pelayanan publik, pengembangan kapasitas organisasi, manajemen, pendanaan, sumber daya, dan sarana prasarana yang memadai.

Kabupaten Kepulauan Tanimbar (KKT) terdapat 10 Kecamatan yang tersebar pada tujuh (7) pulau dimana 4 kecamatan berada pada Pulau Yamdena, sedangkan enam (6) kecamatan berada pada enam (6) pulau yang berbeda, sedangkan Kecamatan Tanimbar Selatan merupakan lokus berada pada pulau Yamdena di pusat KKT. Berdasarkan fenomena saat ini sesuai dengan hasil pengamatan menunjukkan terbatas dukungan infrastruktur seperti gedung sekolah, perkantoran, listrik, jalan, jembatan, 
menyebabkan pelayanan kesehatan, pendidikan yang merupakan kebutuhan primer masyarakat di Kecamatan ini belum mendapat perhatian yang serius dari pemerintah Kabupaten, dan ini di jumpai pada kecamatan Tanimbar Selatan yang berkedudukan di dekat pusat pemerintahan dan pelayanan publik (ibu kota Kepulauan Tanimbar), apalagi enam kecamatan yang berada pada pulau pulau yang memiliki keterbatasan akses pada pusat pemerintahan kabupaten ini sangat mempengaruhi pelayanan publik.

Dalam kajian ini fokus utama reformasi birokrasi pada dimensi kelembagaan (institusional), yang diukur dengan desentralisasi kewenangan, struktur birokrasi, fungsi kewenangan serta teknologi informasi dan komunikasi dengan rtujuan untuk mendeskripsikan dan menganalisis reformasi kelembagaan di Kecamatan Tanimbar Selatan KKT dan dikaitkan dengan pelayanan publik.

\section{Kerangka Teoritis}

\section{Reformasi Birokrasi}

Pada dasarnya Reformasi Birokrasi adalah suatu perubahan signifikan elemenelemen birokrasi seperti kelembagaan, sumber daya manusia aparatur, ketatalaksanaan, akuntabilitas, aparatur,pengawasan dan pelayanan publik, yang dilakukan secara sadar untuk memposisikan diri (birokrasi) kembali, dalam rangka menyesuaikan diri dengan dinamika lingkungan yang dinamis, sebab reformasi birokrasi merupakan salah satu cara untuk membangun kepercayaan rakyat. Ruang lingkup reformasi birokrasi tidak hanya terbatas pada proses dan prosedur, tetapi juga mengaitkan perubahan pada tingkat struktur dan sikap serta tingkah laku.

Hal ini berhubungan dengan permasalahan yang bersinggungan dengan wewenang dan kekuasaan. Reformasi birokrasi adalah sebuah harapan masyarakat pada pemerintah agar mampu memerangi KKN dan membentuk pemerintahan yang bersih serta keinginan masyarakat untuk menikmati pelayanan publik yang efisien, responsif dan akuntabel. Maka dari itu masyarakat perlu mengetahui reformasi birokrasi yang dilakukan saat ini agar kehidupan bernegara berjalan dengan baik, masyarakat juga berposisi sebagai penilai dan pihak yang dilayani pemerintah. Reformasi birokrasi bertujuan untuk;

1. Memperbaiki kinerja birokrasi agar lebih efektif dan efisien. 
2. Terciptanya birokrasi yang profesional, netral, terbuka, demokratis, mandiri, serta memiliki integritas dan kompetensi dalami melaksanakan tugas dan tanggung jawabnya selaku abdi masyarakat dan abdi negara.

3. Pemerintah yang bersih (Clean Government).

4. Meningkatkan kualitas pelayanan terhadap masyarakat.

5. Bebas KKN

Reformasi birokrasi adalah modifikasi-modifikasi dan perbaikan-perbaikan institusional, organisasional dan prosedural dalam birokrasi pemerintah guna meningkatkan responsivitas terhadap warganegara dan bisnis serta memperbaiki efisiensi dan efektivitas (Fountain, 2007). Definisi ini sudah mencakup gagasan working better dan cost less dari Peters, (2001) serta re-orderings struktural dari Goldfinch, S.F., and Wallis, (2009) dan reengineering struktural dari Omoyefa, (2008).

\section{Pelayanan Publik}

Inti dari pelayanan publik adalah suatu kegiatan seseorang maupun kelompok dalam suatu instansi atau perusahaan tertentu dalam rangka memenuhi kebutuhan masyarakat. Pelayanan publik sangat penting karena menyangkut kebutuhkan yang diinginkan masyarakat. Apabila tidak diberikan maka tatanan suatu negara akan berdampak langsung maupun tidak langsung. Apabila pelayanan publik dalam suatu instansi pemerintah akan dilaksanakan maka dibutuhkan suatu sistem atau komponen yang mampu memberikan pelayanan secara maksimal. Salah satu aspek yang paling berperan dalam pemberian pelayanan publik kepada masyarakat adalah aspek sumber daya manusia atau pegawai. Hal ini disebabkan karena pegawai merupakan aset negara yang menentukan baik tidaknya pelayanan publik yang diberikan kepada masyarakat.

Beberapa para ahli yang mengkaji mengenai pelayanan publik maka tentunya harus memiliki nilai-nilai yang mampu mencerminkan kebutuhan masyarakat yang akan dilayani. Oleh karena itu para ahli seperti: Denhardt J. V. and R. B. Denhardt, (2003), Vigoda-Gadot, E. and Cohen, (2004) yang mengadopsi paradigma New Public Management dan terakhir New Public Service (NPS) yang memposisikan masyarakat adalah valuabe/ costumer atau lebih baiknya sebagai owner.

Pelayanan dirumuskan sebagai a total organżational approach that's makes quality of service as perceived by the costomer, the number one driving force for the business (Albreht, dalam Ibrahim, (2008). Dari rumusan tersebut maka dapat diambil kesimpulan bahwa pelayanan merupakan penggerak utama suatu organisasi yang memiliki fungsi 
yang penting dalam keberhasilan organisasi. Menurut Gronroos (dalam Ratminto \& Atik Septi W, (2013) pelayanan adalah suatu aktivitas atau serangkaian aktivitaas yang bersifat tidak kasat mata (tidak dapat diraba) yang tejadi sebagai akibat adanya interaksi antara konsumen dengan karyawan atau hal lain yang disediakan oleh perusahaan pemberi pelayanan yang dimaksudkan untuk memecahkan permasalahan konsumen/pelanggan.

\section{Metode Penelitian}

Penelitian mengunakan jenis penelitian deskriptif dengan pendekatan kualitatif. Penggunaan dan pendekatan penelitian kualitatif dipandang tepat karena sesuai dengan karakteristik kualitatif dengan fenomena yang dikaji, untuk mengverifikasi persoalan reformasi telah dan dapat dilakukan sesuai dengan apa yang diharapkan ataupun sesuai dengan karakter wilayah kepulauan.

Pengkajian ini fokus pada reformasi birokrasi yang lebih difokuskan lagi pada kelembagaan, atau institusi, yang lebih didalami melalui (a) desentralisasi kewenangan, (b) struktur birokrasi, (c) fungsi kewenangan, dan (d) penggunaan teknologi informasi serta komunikasi. Dalam kajian ini dilakukan pengamatan serta diwawancarai beberapa informan yang dapat dipercaya seperti Camat, Kadis, Kepala Desa/Kelurahan dan anggota DPRD, dalam memberi informasi dan data serta dokumen dokumen yang ada. Data dan informasi setelah dikumpul dan dianalisis interraktif oleh Miles, M.B., \& Huberman, A.M., (1994), melalui beberapa tahapan analisis reduksi data, penyajian data, serta penarikan kesimpulan.

\section{Hasil dan Pembahasan}

Reformasi Birokrasi mengidentifikasi bahwa reformasi birokrasi dilihat dari penguatan unit organisasi atau kelembagaan (institusional), reformasi kelembagaan belum ideal sehingga perlu dilakukan beberapa upaya antara lain meliputi; reformasi desentralisasi kewenangan, struktur birokrasi, dan fungsi kewenangan, dan informasi dan teknologi.

\section{Desentralisasi Kewenangan}

Penelitian diawali dengan sebelumnya menelaah preposisi tentang bagaimana desentralisasi kewenangan secara umum dirumuskan secara ideal utuk kemudian ditelusuri dalam praktiknya melalui upaya pemerintah daerah Kabupaten Kepulauan Tanimbar untuk menghilangkan masalah pokok birokrasi melalui reformasi. 
Desentralisasi kewenangan hanya akan terjadi jika ada kemampuan untuk mengelola sumber daya secara mandiri oleh satuan-satuan pemerintahan yang lebih rendah, baik bentuk satuan teritorial maupun fungsional dalam pemeritah daerah sementara itu terdapat kondisi minimnya kekuatan pemerintah kecamatan untuk terlepas dari dominasi dinas-dinas terkait dalam melaksanakan kewenangannya.

Di Indonesia, konstitusi negara kita telah tegas mengatur tentang bagaimana desain desentralisasi kewenangan. Bahwa penyelenggaraan administrasi publik dalam konteks desentralisasikewenangan, sebetulnya telah ditetapkan dalam Undang-Undang Dasar 1945, Pasal 18A yang menyatakan;

1) Hubungan wewenang antara pemerintah pusat dan pemerintahan daerah provinsi, kabupaten, dan kota, atau antara provinsi dan kabupaten dan kota, diatur dengan undang-undang dengan memperhatikan kekhususan dan keragaman daerah.

2) Hubungan keuangan, pelayanan umum, pemanfaatan sumber daya alam dan sumber daya lainnya antara pemerintah pusat dan pemerintahan daerah diatur dan dilaksanakan secara adil dan selaras berdasarkan undang-undang.

Menyimak dengan seksama amanat Undang-Undang Dasar 1945 tersebut, maka tidak ada alasan pembenaran untuk tidak melaksanakan Undang-Undang Dasar tersebut, karena konsekuensi logisnya, jika pemerintah daerah tidak mentaati UndangUndang atau Peraturan Pemerintah maka sanksi hukum jelas akan diberlakukan kepada semua pejabat birokrasi di Indonesia yang tidak patuh terhadap Undang-Undang Dasar 1945.

Desentralisasi kewenangan yang didefinisikan sebagai sebagai transfer perencanaan, pengambilan keputusan dan atau kewenangan administrasi dari pemerintah pusat kepada organisasi pusat di daerah, unit administrasi lokal, organisasi semi otonomi dan parastatal (perusahaan), pemerintah daerah atau organisasi non pemerintah. Perbedaan konsep desentralisasi ditentukan terutama berdasarkan tingkat kewenangan untuk perencanaan, memutuskan dan mengelola kewenangan yang ditransfer oleh pemerintah pusat dan besaran otonomi yang diterima untuk melaksanakan tugas-tugas tersebut.

Dalam hal desentralisasi kewenangan Bupati kepada kecamatan telah tertuang dalam Peraturan Pemerintah nomor 17 tahun 2018 pasal 11 yang menjelaskan bahwa Selain melaksanakan tugas pokoknya, camat mendapatkan pelimpahan sebagian kewenangan bupati untuk melaksanakan sebagian urusan pemerintahan yang menjadi kewenangan daerah dan pelaksanaan tugas pembantuan lainnya. Oleh karena itu 
diawal penelitian difokuskan untuk mencari beberapa kewenangan yang diserakan oleh Pemerintah kabupaten.

Desentralisasi kewenangan atau pengaturan kewenangan melalui pelimpahan wewenang pemerintah daerah kepada pemerintahan Kecamatan, Kelurahan, dan Pemerintah Desa sudah ada, dan diatur dalam peraturan bupati tentang tugas pokok dan fungsi masing-masing OPD. Namun hal tersebut dirasakan masing kurang optimal karena pemerintah kabupaten belum iklas menyerahkan keseluruhan kewenangan yang ada pada kecamatan.

Pemerintah kabupaten mengklaim telah ada transfer kewenangan yang diberikan kepada pemerintah kecamatan sehingga dalam menggali realitas yang terbentuk, penulis kemudian melakukan wawancara dengan pihak kecamatan antara lain;

1) Kegiatan pemberdayaan masyarakat,

2) Urusan penyelenggaraan tugas-tugas pemerintahan umum;

3) Urusan penyelenggaraan pemerintahan desa;

4) Urusan perijinan.

5) Urusan pertanahan

Urusan pembagian kewenangan hal yang menjadi urusan pokok kecamatan menurut undang-undang, kecamatan juga memiliki kewenangan dalam urusan pelayanan umum, pertanahan, perijinan dan pemberdayaan masyarakat desa. Namun kadangkala urusan-urusan ini berbenturan sama kepentingan dinas-dinas terkait. Contohnya saja masalah perizinan, kami harus terus berkoordinasi dengan dinas tata ruang dan catatan sipil, masalah pertanahan dengan kantor pertanahan pemerintahan desa juga degan dinas pemberdayaan desa, pada akhirnya kami hanya berurusan dengah surat-surat pengantar dan disposisi.

Desentralisasi kewenangan kecamatan berubah menjadi hal formal dikarenakan kondisi-kondisi tertentu. Serupa dengan kecamatan Tanimbar selatan, memang punya kewenangan tapi sebatas diatas kertas saja, kalau misalnya ada perencanaan yang dibuat sesuai dengan kewenangan, juga harus selalu dikoordinasikan dengan dinasdinas terkait, saat musrembang misalnya, sudah ada beberapa perencanaan yang dibuat tapi kalau kepala dinas tidak mau maka program yang sudah ditetapkan tidak dapat direalisasikan.

Gambaran diatas telah terlihat upaya pemeritah daerah untuk mendisitribusikan kewenangan yang ada, dalam praktiknya desentralisasi kewenangan ini masih terkendala dengan kurang responsifnya Pemerintah Daerah untuk menjawab usulan 
atau perencanaan program dan kegiatan dari Pemerintah Kecamatan, Kelurahan, dan Pemerintah Desa. Hal menunjukkan bahwa meskipun sudah ada pelimpahan wewenang dari pemerintah kabupaten sampai ke tingkat Desa, namun realisasi perencanaan program dan kegiatan untuk pelayanan publik masih kurang mendapat respon dengan cepat dari Pemerintah Kabupaten Kepulauan Tanimbar.

Selain urusan-urusan diatas, pemerintah kecamatan juga memiliki kewenangan dalam melaksanakan penataan infrastruktur kecamatan sampai ketingkat kelurahan dan desa namun, hasil observasi yang dilakukan peneliti menemukan bahwa masih banyak sarana dan prasaran yang kurang tersedia terutama sarana listrik, gedung pemerintahan yang belum layak, misalnya beberapa desa seperti Desa Matakus dan Desa Lematang dan Kebyarat dimana kantor desa untuk pelayanan masyarakat tidak tersedia dengan baik atau tidak representatif karena kurangnya sarana dan prasarana pendukung. Akibatnya, pelayanan kepada masyarakat banyak dilayani di rumah Kepala Desa atau Sekretaris Desa, pelayanan kesehatan seperti polindes atau puskesmas pembantu dari 10 Desa di wilayah hanya ada beberapa desa seperti Saumlaki, Woworan, Olilit dan Sifnana sudah ada meskipun masih sangat sederhana.

Hasil review dokumen yang dilaksanakan di Kantor Dinas Pemberdayaan Masyarakat dan Desa Kabupaten Kepulauan Tanimbar mengenai usulan perencanaan program pemerintah Kecamatan dan Kelurahan/Desa di Wilayah Tanimbar Selatan sudah banyak menumpuk terutama khususnya pembangunan infrastruktur seperti, gedung sekolah, puskemas, pengadaan kantor desa, polindes, pengadaan bidan desa dan lain-lain.Orientasi program sebagian besar diprioritaskan untuk pembangunan infrstruktur dalam rangka pelayanan publik. Namun, realisasi dari usulan perencanaan pembangunan dan pemberdayaan masyarakat hanya sekitar 34\% yang terealisasi tersebar di 10 Desa. Desa yang paling banyak mendapatkan prioritas pembangunan sarana dan prasarana adalah Kecamatan Tanimbar Selatan karena berada pada kota kabupaten sebagai pusat kegiatan pemerintahan dan arus ekonomi serta perdagangan.

Untuk desentralisasi kewenangan ini, selain dalam bentuk perencanaan infrastruktur dan pemberdayaan, termasuk juga program yang bersumber dari Pemerintah Daerah seperti pemberdayaan perempuan dan ekonomi masyarakat. Namun, secara umum program desentralisasi kewenangan kurang optimal karena semua kebijakan pembangunan dan pemberdayaan serta peningkatan ekonomi kemasyarakatan termasuk pelibatan pihak swasta. Pemerintah Kecamatan dan Desa perlu melakukan koordinasi secara intensif dengan pemerintah daerah meskipun sudah ada dasar hukum yang kuat dalam pelimpahan wewenang untuk menyusun dan/atau 
merencanakan program kebijakan. Dengan demikian dapat dikemukakan bahwa aspek "desentralisasi kewenangan" yang ada dalam konteks reformasi birokrasi pada dimensi kelembagaan (institusional) sudah ada, namun kurang optimal diwujudkan karena responsivitas pemerintah daerah dan dukungan dana baik yang bersumber dari Dana Alokasi Umum atau Dana Alokasi Khusus (DAK) serta APBD relatif masih sangat terbatas, sementara pembiayaan untuk pembangunan dan pemberdayaan sentra-sentra ekonomi masih sangat kurang.

Hasil penelitian menunjukkan bahwa reformasi kelembagaan dalam konteks pelimpahan kewenangan tidak berjalan secara optimal mengingat, pelaksanaan reformasibirokrasi tidak berhasil menuntaskan masalah pokok yang ingin dikejar melalui reformasi yaitu gejala tarik menarik kepentingan antara dinas-dinas dengan kecamatan. Seluruh kondisi diatas mengantarkan penulis pada sebuah simpulan bahwa realitas yang terjadi pada desentralisasi kewenangan dalam upaya mereformasi aspek kelembagaan adalah desentralisasi kewenangan berbanding terbalik dengan kontrol politik terhadap birokrasi. Alokasi anggaran yang tidak berimbang serta prioritas daerah pemenangan pilkada masih berpengaruh besar dalam keluwesan desentralisasi"

\section{Struktur Birokrasi}

Reformasi birokrasi pada tingkat pemerintahan daerah antara lain adalah penataan kembali struktur organisasi perangkat daerah yang diwujudkan dengan dikeluarkannya Peraturan Pemerintah Nomor 41 Tahun 2007 yang menyebutkan bahwa, dalam rangka penyelenggaraan pemerintahan daerah, kepala daerah dibantu oleh perangkat daerah yang terdiri dari unsur staf yang membantu penyusunan kebijakandan koordinasi, diwadahi dalam "sekretariat", unsur pengawas yang diwadahi dalam bentuk "Inspektorat", unsur perencanaan yang diwadahi dalam bentuk "badan", unsur pendukung tugas kepala daerah dalam penyusunan dan pelaksanaan kebijakan daerah yang bersifat spesifik, diwadahi dalam "lembaga teknis daerah", dan unsur pelaksana urusan daerah yang diwadahi dalam bentuk "dinas".

Pengesahan UU Nomor 5 tahun 2014 tentang Aparatur Sipil Negara yang kemudian berlaku efektif dimulainya babak lanjutan pembenahan birokrasi pemerintah Indonesia. Tidak terasa fase pertama reformasi birokrasi yang diinisiasi melalui penerbitan Perpres nomor 81 tahun 2010 tentang Grand Design Reformasi Birokrasi 2010-2025 akan berakhir pada tahun 2014. Masih ada dua fase reformasi birokrasi didepan yang masih menjadi pekerjaan rumah pemerintah hasil pemilihan umum tahun 2014 dan 2019, yaitu fase kedua (2015-2019) dan fase ketiga (2020-2024). 
Dalam menggali tentang wajah reformasi birokrasi di Kabupaten Kepulauan Tanimbar, terhusus untuk penataan birokrasi tentu saja dilihat dari orientasinya dalam menghilangkan masalah pokok yang ada dalam struktur birokrasi dimana struktur menggambarkan bagaimana seharusnya organisasi disusun dan dirancang agar menjadi lebih efisien sehingga seharusnya ada relasi antara besar struktur, kapasitas aparat terhadap tujuan dan cara pencapaian tujuan organisasi, sementara itu struktur yang yang tidak ideal menjadi masalah klasik dalam birokrasi.

Struktur menggambarkan bagaimana seharusnya organisasi disusun dan dirancang agar menjadi lebih efisien sehingga seharusnya ada relasi antara besar struktur, kapasitas aparat terhadap tujuan dan cara pencapaian tujuan organisasi yang merupakan preposisi awal, memberikan gambaran bahwa struktur birokrasi dalam konteks reformasi birokrasi merupakan salah satu aspek penting selain aspek-aspek lainnya.

Saat ini struktur birokrasi Pemerintah Kabupaten Kepulauan Tanimbar bhususnya ditingkat kecamatan dengan Unit Pelaksana teknis masih mengalami keterbatasan dalam melaksanakan pelayanan hal ini disebabkan karena masih terbatasnya SDM yang cakap dalam melakukan kefgiatan kegiatan pelayanan pada masyarakat, hal ini mengindikasikan bahwa perlu regrutmen ASN sebab rata rata pada UPT mengalami keterbatasan dengan hal dimaksut, dan masih didominasi oleh tenaga tenaga honor, yang jelas sangat minim dalam melaksanakan kegiatan kegiatan p[elayanan kepada masyarakat.

Struktur birokrasi di Kabupaten Kepulauan Tanimbar khususnya di Kecamatan sudah sesuai dengan Peraturan Pemerintah Nomor 18 tahun 2016 tentang perangkat daerah. Akan tetapi dalam melihat efeknya terhadap peningkatan kualitas pelaksanaan tugas dan kewenangan penulis beranggapan belum sepenuhnya sejalan dengan orientasi dari reformasi birokrasi mengingat hasil obsevasi yang dilaksanakan ternyata masih banyak keluhan dari masyarakat terutama dalam pelayanan public, pelayanan sertifikat tanah, pembuatan surat akte kelahiran, dan Kartu Tanda Penduduk serta ijin ijin usaha lainnya yang mestinya dapat dilakukan oleh Unit Pelaksana Teknis di Kecamatan yang masih dirasakan sangat rumit serta banyaknya unit-unti yang terlibat, kesan masihtumpang tindihnya kewenangan antar unit pelayanan bahkan antar instansi masih mewarnai pelaksanaan fungsi-fungsi kecamatan, tidak jarang, beberapa dokumen yang seharusnya bisa dieksekusi langsung dikecamatan malah harus dikirim terlebih dahulu ke ibukota kabupaten tempat lokasi instansi sektoral yang bertanggung jawab untuk beberapa formalitas yang sebenarnya bisa dilakukan pemangkasan. 
Artinya, reformasi struktur birokrasi di daerah ini belum sepenuhnya sesuai dengan tujuan yang diinginkan. Kesimpulan ini juga diperkuat dengan tingginya opini negatif dari masyarakat mengenai birokrasi yang berbelit-belit.

Hasil ada perbedaan kecamatan yang berdekatan dengan ibukota Kabupaten dengan di Kecamatan kepulauan artinya yang berada pada pulau pulau yang jaraknya cukup jauh Kalau dengan transportasi KM. Feri yang biasanya melakukan perjalanan antara pulau kadan 8 - 24 jam perjalanan, meskipun dengan kadar restrukturisasi birokrasi yang seragam akan tetapi pelayanan publik belum juga mendapatkan kepuasan dari masyarakat apalagi kecamatan kecamatan yang berada pada pulau pulau, seperti mengurus izin membuka usaha atau surat akte kelahiran dan sengketa lahan masih terkesan lambat dan bisa mencapai 1 minggu. Padahal dari hasil observasi yang dilakukan untuk menyelesaikan urusan persuratan bisa diselesaikan dalam jangka waktu 1 hari. Ada beberapa masalah yang teridentifikasi berkaitan dengan struktur birokrasi yakni;

1) Tenaga terampil masih kurang,

2) Sarana pendukung seperti listrik dan komputer dan printer masih terbatas,

3) Spesialisasi tugas kurang sehingga terjadi tumpang tindih pekerjaan,

4) Tidak ada standar operasional prosedur dalam pelayanan publik, dan

5) Motivasi pelayanan public aparatur kecamatan kurang optimal.

6) Masih ketidak relaan sebagian tugas yang seharusnya tidak perlu dilakukan ditingkat kabupaten apalagi daerah pulau

Pada dasarnya penghambat dalam pelayanan terutama karena keterbatasan tenaga atau staf yang pada umumnya masih status honor sehingga kesulitan dalam disiplin kantor apalagi honor yang diberikan per bulan sangat kecil dibawah UMR Propinsi perbulan 2.200.000, kecamatan Rp. 500.000 - Rp. 1.000.000, selain itu belum adanya standar operasional prosedur dalam penyelesaian tugas.

Sedangkan terkait struktur organisasi, sudah melakukan beberapa upaya untuk merestrukturisasi semua Organisasi Perangkat Daerah sesuai dengan Peraturan Pemerintah Nomor 18 tahun 2016 tentang perangkat daerah dan Peraturan Menteri Dalam Negeri Nomor 12 Tahun 2017. Tentang. Pedoman Pembentukan Dan Klasifikasi Dinas, dan Unit Pelaksana Teknis Daerah. Namun, memang diakui sebetulnya masih dapat dirampingkan struktur organisasi saat ini agar supaya pekerjaan lebih terfokus dan efisien. Masalah lain juga adalah kesiapan aparatur di tingkat kecamatan, kelurahan, dan desa masih perlu ditingkatkan kompetensinya termasuk pengadaan pegawai. 
Kendala lain juga karena motivasi pelayanan publik pegawai masih rendah, ini yang masih perlu diperbaiki ke depan dalam upaya memperbaiki kinerja birokrasi pemerintah.

Reformasi birokrasi dari aspek struktur birokrasi masih perlu pembenahan terutama dari kemampuan dan kapasitas pegawai, pengadaan pegawai negeri sipil, pengadaan sarana dan prasarana pendukung pelayanan publik, dan pemberdayaan pegawai melalui peningkatan motivasi pelayanan publik. Selain itu, penting dan mendesak agar dalam mendesain struktur organisasi perlu diisi oleh tenaga-tenaga terampil dan profesional yang mampu memanfaatkan peluang dan kekuatan daerah yang ada sehingga dapat meningkatkan pendapatan asli daerah. Untuk masalah yang terakhir ini, penulis menemukan struktur birokrasi diisi oleh orang-orang yang tidak memiliki kompetensi yang memadai dalam memahami tujuan dari reformasi birokrasi sehingga kesalahan dalam menyikapi tugas-tugas birokrasi, dan terkesan ada pembiaran yang terjadi. Dengan demikian dapat disimpulkan bawa kompleksitas dalam pengelolaan urusan birokrasi tidak ditopang oleh keahlian manajemen organisasi, akibatnya pelaksanaan beban kerja menjadi berlipat dan berpengaruh pada skala prioritas kerja dan pencapaian kinerja

\section{Kewenangan}

Mengenai fungsi kewenangan, idealnya setiap satuan organisasi yang dalam pelaksanaan tugasnya didasarkan pada keahlian serta keterampilan tertentu untuk mencapai tujuan maksimal serta memiliki kemandirian dalam pelaksanaannya hanya saja masalah yang muncul dalam organisasi adalah masih banyaknya ketidak jelasan fungsi dan tumpang tindih kewenangan oleh karena itu dalam melihat realitas pelaksanaan reformasi birokrasi

Sudah menjadi hakikatnya birokrasi lahir berfungsi untuk memberikan pelayanan kepada masyarakat terutama yang bersifat impersonal. Birokrasi adalah sarana untuk melayani masyarakat dan bukan untuk dilayani. Tidak bisa dipungkiri bahwa fungsi kewenangan birokrasi saat ini masih menjadi kajian para ahli mengingat lambatnya implementasi tugas dan fungsi kewenangan birokrasi. Gie, K.K., (2003) menyatakan bahwa ada kecenderungan yang terjadi saat ini adalah bahwa dalam penyusunan suatu organisasi cenderung lebih ditekankan pada bagan strukturnya saja, dan melupakan jumlah dan kualifikasi personel, sistem pengambilan keputusan, sistem komunikasi serta rentang kendali organisasi (span of control). Struktur organisasi birokrasi yang demikian akan menyempitkan strategi yang dapat dipilih atau digunakan.

Pendekatan ini lebih dikenal dengan strategy follows structure. Berbagai permasalahan dibidang kelembagaan dapat dikelompokkan ke dalam 3 (tiga) hal yang 
meliputi: (a) masalah kondisi struktur birokrasi yang tumpang tindih; (b) ketidakjelasan fungsi-fungsi yang harus dilaksanakan pemerintah dengan yang harus menjadi bagian dari tugas masyarakat; dan (c) belum adanya proses politik yang transparan dalam perumusan dan penetapan kebijakan publik.

Demikian pula dibidang manajemen birokrasi publik masih dihadapkan pada permasalahan antara lain: (a) rencana kerja dan penugasan yang tidak jelas; (b) sistem rekruitmen tidak sesuai dengan prosedur dan kebutuhan; (c) masih rendahnya penegakkan sistem ganjaran dan hukuman; dan (d) tidak adanya ekspose kinerja birokrasi pemerintah secara transparan sehingga tidak ada umpan balik untuk perbaikan kinerja (Gie, K.K., 2003).

Berkaitan dengan aspek fungsi kewenangan dalam konteks reformasi birokrasi sangat penting dilakukan mengingat fungsi kewenangan yang tidak jelas akan menyebabkan kekaburan dalam penyelenggaraan tugas. Fungsi kewenangan bersifat internal karena menyangkut distribusi tugas pokok dan fungsi pada organisasi kecamatan itu sendiri. Fenomena tentang fungsi kewenangan perlu direformasi karena banyaknya pegawai yang dalam satu organisasi merasa kecewa karena tugas yang diberikan seringkali bertentangan dengan tupoksi bidang tertentu. Jadi, fungsi kewenangan sering kali diselewengkan oleh pejabat yang lebih tinggi dalam mengatur para bawahanya.

Fungsi kewenangan ini hendaknya disesuaikan dengan tugas pokok dan fungsi bidang atau seksi. Karena ini menyangkut kinerja setiap bidang atau seksi. Banyak staf yang tidak senang bekerja karena sering tugas pokok dan fungsinya yang harus melaksanakan pekerjaan, tetapi serahkan kepada bidang atau seksi lain. Ini masih yang terjadi sampai saat ini sehingga perlu memang untuk dilakukan reformasi". Fungsi kewenangan yang ada saat ini belum berjalan dengan baik khususnya dalam pelayanan publik. Kondisi nyata yang dialami pegawai di Kantor kecamatan sesuai hasil observasi yang dilakukan peneliti menunjukkan bahwa masih ada pembagian tugas dan kewenangan tidak sesuai dengan tugas pokok dan fungsi yang dimiliki oleh aparatur yang ada. Dampak negatifnya adalah banyak urusan publik menjadi terhambat atau bahkan sampai terbengkalai karena saling lempar tugas dan tanggung jawab hal ini terjadi karena sering menganggap bahwa tugas yang diberikan tidak sesuai dengan tupoksinya.

Fenomena overlaping fungsi kewenangan juga terjadi pada skop yang lebih luas pada level pemerintah daerah sampai kecamatan, dimana fungsi kewenangan ini sering tidak disesuai dengan kapasitas dan kompetensi aparatur melainkan lebih dominan 
dilakukan berdasarkan faktor suka dan tidak suka. Jadi, kalau pejabat yang dianggap baik atau disenangi oleh pejabat yang lebih tinggi maka mereka yang melakukan tugas itu. Meskipun jika dilihat dari pembagian tugas pokok dan fungsi tidak sesuai.Oleh karena itu, reformasi birokrasi menyangkut fungsi kewenangan masih mendesak untuk dilakukan untuk menciptakan birokrasi yang efektif dan efisien di kecamatan.

Hasil penelitian diatas maka penulis memberikan 3 temuan yang signifikan untuk dilakukan yaitu penyelesaian tugas terkendala karena distribusi tugas yang tidak merata dan tidak tepat sasaran; kedua, beban kerja berlebih sehingga menurunkan kinerja; dan ketiga, faktor like dan dislike masih mempengaruhi pelaksanaan kewenangan dan berlangsung dua arah. Dengan demikian tingkat diferensiasi atau pembagian kerja yang ada dalam organisasi baik secara hirarki maupun unit-unit organisasi yang tersebar berbanding terbalik dengan kapasitas birokrasi yang mengisi jabatan sehingga kerapkali terjadi tumpang tindih kewenangan atau melemahnya kinerja"

\section{Teknologi Informasi dan Komunikasi}

Bentuk reformasi birokrasi dari aspek teknologi informasi dan komunikasi adalah terwujudnya sistem electronic government (e-government) dalam penyelenggaraan pemerintahan dan pelayanan publik. Asal muasal teorinya bersumber dari Teor stakeholder (stakeholders theory) ditemukan oleh Freeman, R.E., (1984) yang menyatakan bahwa; the traditional definition of a stakeholder is "any group or individual who can affect or is affected by the achievement of the organziation's objectives" (Freeman, R.E., 1984, 1999, 2004). Teori ini kemudian dikembangkan oleh Zimmermann, P., \& Finger, (2005) bahwa organisasi memerlukan dukungan dari teknologi dan pihak lain dalam perusahaan swasta yang kemudian diaplikasikan dalam organisasi sektor public sebagai keputusan manajerial dari e-Government.

Pelaksanaan reformasibirokrasi dari aspek teknologi informasi dan komunikasi terus kami kembangkan, namun sampai saat ini masih terkendala dengan dukungan sarana dan prasarana terutama listrik dan internet. Reformasi dalam bidang ini sangat penting untuk pelayanan publik yang efisien dan efektif". Dalam rangka pelayanan publik yang baik dan efektif tentu memerlukan dukungan sarana dan prasarana melalui teknologi informasi dan komunikasi, hanya memang untuk pengembagannya khususnya disetiap desa, kelurahan, dan kecamatan belumm erata. Salah satu faktornya adalah keterbatasan anggaran untuk menyiapkan sarana dan prasarana pendukung.

Pada prinsipnya Pemerintah Daerah untuk mempersiapkan model pelayanan publik yang berbasis teknologi, komunikasi dan informasi. Hal ini penting dilakukan 
karena akan mendukung kemudahanan dalam memberikan pelayanan kepada masyarakat terutama informasi yang diperlukan. Usulan melalui musrenbangkecamatan sudah ada, namun untuk mewujudkan program ini tentu didasarkan pada kemampuan anggaran daerah.

Reformasibirokrasi pada aspek teknologi informasi di Kecamatan Tanimbar Selatan belum ada optimal. Hal ini disebabkan oleh kurangnyaanggaran pemerintah daerah dalam mempersiapkan sarana dan prasarana pendukung, tenaga terampil dan berpengalaman, serta keterbatasan anggaran, di Kantor Camat Tanimbar Selatan pelayanan publik yang berbasis teknologi atau inovasi pelayanan publik masih sangat kurang. Pada umumnya masyarakat masih dilayani dengan cara manual dan mereka datang ke kantor Camat Tanimbar Selatan untuk mengurus berbagai bentuk pelayanan yang dibutuhkan.

Beberapa desa seperti Desa Lermatang, Latdalam, dan Matakus pada umumnya mendapat informasi kegiatan di kecamatan melalui pengumuman yang disampaikan secara lisan atau melalui handphone ( $\mathrm{hp}$ ) meskipun sangat terbatas karena belum dibangun sarana komunikasi seperti telkomsel atau kantor telkom yang dapat menjadi sumber informasi yang akurat. Berdasarkan hasil review di kantor Camat Tanimbar Selatan ternyata belum ada website atau blog Pemerintah Kecamatan Tanimbar Selatan, berkas-berkas atau dokumen masih bersifat manual, dan ada juga masyarakat yang harus membuat usulan berkas berkali-kali karena berkasnya hilang. Artinya, dukungan informasi yang berbasis teknologi masih sangat kurang, dan tentu saja ini berdampak negatif terhadap rendahnya pelayanan publik yang diberikan kepada masyarakat. Sehingga tidak mengherankan jika masyarakat merasa kurang puas atau tidak percaya dengan pelayanan publik yang diberikan oleh aparatur Pemerintah Kecamatan Tanimbar Selatan KKT.

Kondisi yang ada bertolak belakang dengan teori tentang pentingnya dukungan teknologi informasi dan komunikasi. Hal ini tentu merupakan tangung jawab pemerintah kecamatan dan pemerintah KKTsebagai pemegang kekuasaan pemerintah daerah dan penentu kebïakan. Karena bagaimana pun, tanggungjawab manajemen dimulai dengan mengatur pekerjaan tidak hanya secara formal tetapi juga jaringan organisasinya (Scholl, B.J., Pylyshyn, Z.W., \& Feldman, 2001).

Dengan demikian dapat dikemukakan bahwa dimensi reformasi kelembagaan kecamatan Tanimbar Selatan sudah berjalan, namun kurang efektif dilihat dari 
desentralisasi kewenangan, struktur birokrasi, fungsi kewenangan, dan dukungan teknologi informasi dan komunikasi.

\section{Penutup}

\section{Kesimpulan}

Reformasi kelembagaan di Kecamatan Tanimbar Selatan KKT kurang efektif dilakukan disebabkan oleh beberapa permasalahan yang dihadapi terkait dengan upaya pemerintah kecamatan dalam melakukan reformasi birokrasi; desentralisasi kewenangan kurang berjalan dengan efektif karena desentralisai kewenangan yang diberikan tidak sepenuhnya berjalan sesuai dengan yang diharapkan. Dari aspek struktur organisasi sudah menerapkan prinsip-prinsip yang diatur dalam Peraturan Pemerintah Republik Indonesia Nomor 18 Tahun 2016 Tentang Perangkat Daerah, mengedepankan aspek kepentingan dan kebutuhan serta ketersediaan anggaran Pemerintah Daerah. Sarana pendukung masih sangat kurang terutama dukungan teknologi informasi dan komunikasi yang masih menjadi penghambat dalam memberikan pelayanan yang efektif dan efisien.

\section{Saran}

Desentralisasi kewenangan Pemerintah Kecamatan terbatas pada fungsi perencanaan program, namun terbatas pada pengambilan keputusan yang bersifat strategis seperti penetapan anggaran. Oleh karena itu, reformasi kelembagaan perlu melibatkan pemerintah kecamatan dalam rangka penyusunan, penetapan, implementasi, dan pengendalian anggaran. Paling tidak ada kunci utama yang direkomendasikan kepada Pemerintah Daerah KKT dan Pemerintah Kecamatan Tanimbar Selatan yaitu; diperlukan reformasi birokrasi dalam pelayanan publik berdasarkan dimensi kelembagaan dengan memberikan kewenangan yang lebih pada kecamatan termasuk didalamnya Unit Unit Pelaksana teknis sehingga mampu dengan tepat dan cepat melaksanakan upaya pelayanan publik kepada masyarakat.

\section{Daftar Pustaka}

Dahyar Daraba H. (2019). Reformasi Birokrasi \& Pelayanan Publik. Penerbit Eisyah.

Denhardt J. V. and R. B. Denhardt. (2003). The New Public Service; Serving, not Steering. New York: M.E. Shape.

Economic Commission for Africa. (2003). Public Sector Management Reforms in Africa: Lessons Learned. Development Policy Management Division (DPMD). Retrieved 
from ECA/DPMD/PSM/TP/03/1

Farazmand, A. (2007). Bureaucracy and Administration. New York: CRC Press.

Fatile, Jacob O. and Adejuwon, K. D. (2010). Journal of Sustainable Development in Africa. Sustainable Development, 12(8), 90-99.

Fountain, J. E. (2007). Bureaucratic Reform and E-Government in the United States: An Institutional Perspective. A Pre-Publication Version of a Chapter to be Printed Andrew Chadwick and Philip N. Howard (Eds). The Handbook of Internet Politics. New York: Routledge.

Freeman, R.E. (1984). Strategic Management: A Stakeholder Approach. Boston: Pitman, MA.

Freeman, R. . (1999). Response: Divergent Stakeholder Theory. Academy of $\begin{array}{llll}\text { Management } & \text { 24(2). } & \text { Review, }\end{array}$ https://www.jstor.org/stable/259078?seq $=1$

Freeman, R. E. (2004). "A Stakeholder Theory of Modern Corporations, "In Ethical Theory and Business. Prentice Hall.

Gie, K.K. (2003). Reformas iBirokrasi Dalam Mengefektifkan Kinerja Pegawai Pemerintahan. Jakarta.

Goldfinch, S.F., and Wallis, J. . (2009). International Handbook of Public Management Reform. Cheltenham, UK: Edward Elgar Publishing Limited.

Ibrahim, A. (2008). Teori dan Konsep Pelayanan Publik Serta Implementasinya. Bandung: Mandar Maju.

Kaufman, H. (2011). Major Players: Bureaucracies in American Government. Public Administration Review, 61(1), 18-42. Retrieved from https://uww.jstor.org/stable/977534?seq=1

Kiragu, K. and Mukandala, R. (2003). Service Pay Reform, Tactics Sequencing And Politics In Developing Countries: Lessons From Sub-Saharan Africa. Retrieved from uww1.worldbank.org/.../PayReformStud...

Miles, M.B., \& Huberman, A.M. (1994). Qualitative Data Analysis: An Expanded Sourcebook. New York: Sage Publicatio Inc.

Omoyefa, P. S. (2008). Public sector reforms in Africa: A philosophical re-thinking. Africa Development, 33(4), 15-30. https://doi.org/10.4314/ad.v33i4.57332

Peters, B. G. (2001). The Politics of Bureaucracy. London: Routledge.

Priyono, T. (2014). Reformasi Sistem Birokrasi di Era Jokowi. Detik News. Com. 
Ratminto \& Atik Septi W. (2013). Manajemen Pelayanan. Yogyakarta: Pustaka Pelajar. Ridley, F. F. (1982). Administrative Theory and Administrative Reform. "In Strategies for Administrative Reform. Toronto: Lexington Books.

Scholl, B.J., Pylyshyn, Z.W., \& Feldman, J. (2001). What is a Visual Object? Evidence from Target Merging in Multiple Object Tracking. Cognition, Elseiver.

Syquia, J. L. C. (2007). Reforming Public Procurement in Emerging Market Countries. Produced for Review by the United States Agency for International Development.

Victorio Fernando Nahuway \& Eduard Yohannis Tamaela. (2020). Model Efektifitas dan Efisiensi E-Procurement serta Dampaknya Terhadap Kepuasan Pengguna di Provinsi Maluku. JURNAL MANEKSI, $9(1), 275-282$. Retrieved from http://ejournalpolnam.ac.id/index.php/JurnalManeksi/article/view/327/351

Vigoda-Gadot, E. and Cohen, A. (2004). Citzienship and Management in Public Administration: Integrating Behavioral Theories and Managerial Thinking. Cheltenham, etc: Edward Elgar.

Zimmermann, P., \& Finger, M. (2005). . Information- and Communication Technology (ICT) and Local Power Relationships: An Impact Assessment. The Electronic Journal of E-Government, 3(4), 231-240. 